\title{
THE EFFECT OF COMMUNICATION APPROACH ASSISTED AUDIO VISUAL TO IMPROVE THE STUDENTS' LISTENING ACHIEVEMENT
}

\author{
Zahara Marhamah Siregar \\ English Applied Linguistics Department, Postgraduate Program \\ State University of Medan, North Sumatera, Indonesia \\ Corresponding author: zahara.zms73@gmail.com
}

\begin{abstract}
The objective of this study is to investigate The Effect of Communication Approach Assisted Audio Visual as Media on the Students' Achievement in listening comprehension. This is an experimental research which applied descriptive quantitative method to describe the result (Syahrum, 2012: 34). This study was conducted at Madrasah Aliyah, islamic bording school of Darul Qur'an. The population of this research was tenth grade. The instruments for collecting data in this research was written test in form multiple choice test, consist of 20 questions. Pre-test and post-test were conducted in both, experimental and control group. The finding showed that the students who are taught by using Communication Approach Assisted Audio Visual as Media got higher score than those who taught by using audio media. The test result showed that there was significant effect of using Communication Approach Assisted Audio Visual as Media on the students' achievement in listening comprehension which was proven for the result of analysis, $t_{0}$ was higher than $t_{t}(2,47>2,024)$ at $\alpha 0,05$, and $\mathrm{df} 38$. It means the hypothesis alternative was accepted.
\end{abstract}

Keywords: communication, listening achievement, audio visual

\section{Introduction}

The important aspect in society is language. It is use as means of communication in activity. Language is used to exchange information among people (Halliday, 1994). There are languages in the world. One of them is English. English is an International language being used all over the world. In Indonesia, English is taught as a foreign language as stated in 1994 National Curiulum. It is true that English is not a native language for Indonesian. So, it is reasonable for Indonesian, especially the students find some difficulties in studying it. Listening is one of the hardest things for students because they tend not to understand what the other person is talking about.

Listening is activity to identify and understand what others are saying. Brown (2001: 247) mention that the importance of listening in language learning can hardly be overestimated. Listening is not just the process of hearing the sounds but it is a process of construction interpretation to the speakers' utterances. Alan (2005: 69) says "the complementary skill of listening is just as important as talking but is often 
Proceedings of the $1^{\text {st }}$ Annual International Conference on Language and Literature (AICLL), 18-19 April 2018, Fakultas Sastra, UISU, Medan, Indonesia.

overlooked". It can be concluded that listening is very important for our communication, when we cannot listen well, of course we will not receive the information given by the speaker, it will also cause some misunderstanding.

Teaching listening was considered by many language teachers as a challenging task due to the fact that learners believed that it was a difficult skill to develop during the process of learning any foreign language. It was caused by many factors such as stress, pronunciation and the culture component made the language more complex at the moment of understanding it.

Another problem was the teaching method, strategy or approach used by the teacher. The teacher usually only gave test to the students. They spread script, play the record, then the students had to answer the test well. Of course, it made the students confused and not interested in learning process. The question was how come the students could answer the test correctly, while they were never taught about listening skill. They were never trained to have a good listening skill. Actually, it was the teacher duty to teach them in a good atmosphere. In the other side, what made the teacher seldom taught listening was caused by the facility in the school. Many school had not language labaratory. It caused the teacher could not give the students listening material.

Richards and Rodgers (2001: 19) said that an approach is a set of correlative assumption dealing with the nature of language and the nature of language learning and makes statements about the conditions which will promote successful in language learning. In the literature of English language teaching, the term "method and approach" are often use in the nature of language learning. Basically, both of those terms do not have same meaning.

One effective appproach to teach listening comprehension is communication approach. Communication makes use of real life situation with the help of communication. The teacher is supposed to create a situation in which every student has to answer the foremost function of the language. The main Elements of Communication approach are: (1) communication as per talent, (2) accuracy and fluency, (3) continuous learning process, (4) motivation among students (Mittal, 2000: 2)

Based on the description above, Media is one of the important factors affecting in teaching learning process especially listening. It is considered can help the English teachers to teach effectively and learners to be more interested and motivated in learning English.

\section{Literature Review}

Media is the plural form of medium. According to Murcia,"media are tools or physical things used by the teacher to motivate the students by bringing a slice of real life into the classroom and presenting language in its more complete communication complex."it can also be said that media is important in teaching and learning english 
Proceedings of the $1^{\text {st }}$ Annual International Conference on Language and Literature (AICLL), 18-19 April 2018, Fakultas Sastra, UISU, Medan, Indonesia.

because media help teachers to delivern the material being taught. Beside, the students can understand the material more easily because media is a good way to engange the students in learning english.

Communication Approach can be understood as a set of principles about the goals of language teaching, how learners learn a language, the kinds of classroom activities that best facilitate learning, and the roles of teachers and learners in the classroom. Let us examine each of these issues in turn.(Richard, 2006: 2).

Mittal (2000: 37) says that communication approach makes use of real life situation with the help of communication. The teacher is supposed to create a situation in which every student has to answer which is the foremost function of the language. The main elements of Communication approach are: Communication as per Talent; Accuracy and Fluency; Continuous learning process; and, Motivation among students

CLT enhances the learners' confidence and it gives a sense of satisfaction to the teacher as well in the sense that $s /$ he is successful in making the students use the foreign language in their conversation. CLT gives clarity to the expression. Communicative approach is better than all the other methods of language teaching in general. (Mehmood and Akram, 2011). In this approach, the use of authentic materials is highly emphasized. Teachers are encouraged to use different audio-visual aids in a CLT classroom. As the materials are mostly authentic, there are wide ranges of use of the pictures and videos in the classroom to make the class interesting and authentic. Usually, the class activities are based on the activities that are related to real communication. As a result, the learners are shown different visual aids like map for giving direction, picture for describing any place or person and so on(Freeman in Mamun, 2014: 2).

The procedure of audiovisual media in teaching listening in classroom as follows:

a. The teacher will select a video that connected the material

b. The teacher will give sheets to the students as a test

c. The teacher will explain the material before play the video

d. The teacher will play the video and give intruction for the students to look and listen the video with carrefully

e. The teacher will ask students to fill the blank part in the sheet by look and listen the video

f. The teacher will collect the students sheets and correct them

g. The teacher will give score for the students

Using Audio Visual media has some advantages, such as :

1. Used auditory and visual sense for more effective learning

2. Effective for role-modeling, demonstration and teaching psychomotor skills

3. Many students like tv medium, as it's attractive and persuasive

4. The students didn't bored learning with media

Contrast, it also gives some disadvantages such as : 
Proceedings of the $1^{\text {st }}$ Annual International Conference on Language and Literature (AICLL), 18-19 April 2018, Fakultas Sastra, UISU, Medan, Indonesia.

1. Only hearing stimulated

2. Lack interaction between teacher-learner

3. Listening requires concentration

On the other hand, we will find out some aspects which influence on mastering listening comprehension, they are hearing the sound and video, understanding intonation and stress, coping with redundancy and noise, predicting understanding colloquial vocabulary, fatigue, understanding different accent using audio visual and environment clues. These aspects can be a problem for listener if they do not master English well but the most important of them, the listener should master the listening and pronunciation in English, because without mastering them, the listener can not interpret the massage of the spoken language.

\section{Research Method}

An experimental research design was applied in this research. Experimental design aimed to get the relation between cause effects clearly and between the cause factors with the problem of research (Syahrum, 2012: 34). The design was applied in order to investigate the effect of communication approach assisted audio visual media in listening comprehension.

Table 1. Research Design

\begin{tabular}{|c|c|c|c|}
\hline Group & Pre-test & Treatment & Post-test \\
\hline Experimental & $\checkmark$ & $\mathrm{X}$ & $\checkmark$ \\
\hline Control & $\checkmark$ & $\mathrm{Y}$ & $\checkmark$ \\
\hline
\end{tabular}

Where:

$\mathrm{X}$ : the experimental group where the students taught by using Communication Approach Assisted Audio Visual as Media

$Y=$ the control group where students were taught by using audio media.

\section{Pre-test}

Both groups, the experimental group and control group were given pre-test before the treatment. The pre-test was administrated to both groups with the same test. The pre-test was useful to know the mean score of experimental and control group.

\section{Teaching Presenting (Treatment)}

The experimental and control group were taught by using same material, that was listening but different in treatment. It meant that in the experimental group was taught by using communication approach assisted audio visual media, while in the control group was taught by using audio media.

Table 2. The Experimental and Control Groups

\begin{tabular}{|c|l|l|}
\hline No & \multicolumn{1}{|c|}{ Experimental group } & \multicolumn{1}{c|}{ Control group } \\
\hline 1 & Teacher greets the students to open the class. & Teacher greet the students to open the class. \\
\hline 2 & $\begin{array}{l}\text { The teacher motivated the students by } \\
\text { explaining that listening comprehension is } \\
\text { a key to understand spoken language. }\end{array}$ & $\begin{array}{l}\text { The teacher motivated the students by } \\
\text { explaining } \\
\text { that listening comprehension is a key to } \\
\text { understand spoken language. }\end{array}$ \\
\hline 3 & $\begin{array}{l}\text { The teacher gave a brainstorming (Who am I } \\
\text { game) }\end{array}$ & $\begin{array}{l}\text { The teacher gave a brainstorming (Who am I } \\
\text { game) }\end{array}$ \\
\hline
\end{tabular}


Proceedings of the $1^{\text {st }}$ Annual International Conference on Language and Literature (AICLL), 18-19 April 2018, Fakultas Sastra, UISU, Medan, Indonesia.

\begin{tabular}{|c|l|l|}
\hline 4 & $\begin{array}{l}\text { The teacher selected a video relates to the } \\
\text { material }\end{array}$ & The teacher spread the script \\
\hline 5 & The teacher spread the sheet as a test & The teacher played the record for 3- 4 times \\
\hline 6 & $\begin{array}{l}\text { The teachers explained the material before } \\
\text { playing the video }\end{array}$ & $\begin{array}{l}\text { The teacher asked the students to submit } \\
\text { the script. }\end{array}$ \\
\hline 7 & $\begin{array}{l}\text { The teacher played the video and gave } \\
\text { instruction to the students to look and listen } \\
\text { the video carefully. }\end{array}$ & $\begin{array}{l}\text { The teacher spread the script to different } \\
\text { students }\end{array}$ \\
\hline 8 & $\begin{array}{l}\text { Teacher asked the students to answer the test } \\
\text { by looking and listen the video. }\end{array}$ & $\begin{array}{l}\text { The teacher and the students corrected the } \\
\text { works together by listening the record again }\end{array}$ \\
\hline 9 & $\begin{array}{l}\text { The teacher collected the answer sheet and } \\
\text { correct them }\end{array}$ & $\begin{array}{l}\text { The teacher asked the students to submit } \\
\text { the corrected work }\end{array}$ \\
\hline
\end{tabular}

\section{Discussion}

The instrument for collecting the data was written test in form multiple choice test. The students were asked to answer 20 numbers of test that was given to them. The scoring system used this formula:

$$
\mathrm{S}=\frac{R}{N} x 100
$$

The data of this research was the students' answer which was collected by giving the students a test consisting of twenty items. There were 38 students as samples involved in this research. Samples were divided into two groups namely experimental group and control group. Each group was given a pre-test and post-test.

From all the data of the pre-test and post-test of the experimental group and control group obtained, then the researcher analyzed the data into statistic calculation to find out the differences of samples' score between pre-test and post-test in the experimental group. Based on the table above, the following tables 4-3 showed the calculation to find out the mean, the standard deviation, and the standard error between both experimental and control groups.

Based on the calculation of t-test, it was found that t-test was 2,47 and based on the t-table level of significant of 0.05 degree of freedom $38(\mathrm{Nx}+\mathrm{Ny}-2) \mathrm{t}$-table was 2,024. Based on the calculation of t-test, where $t_{0}(2,47)$ was higher than $t_{\text {table }}$ at the level significant of $0.05(2,024)$, therefore, the hypothesis was accepted because $t_{0}>t_{\text {table }}$ or 2,47 $>2,024$. It was concluded that using Communication Approach Assisted Audio Visual Media had significantly increase the students' listening achievement at $10^{\text {th }}$ grade students of MA Darul Qur'an.

The result of this research showed that there was a significant effect of using Communication Approach Assisted Audio Visual Media to students' achievement in listening achievement It was proven by the result of $t_{t e s t}$ that $t_{o}>t_{t}=2,47>2,024$ ( $\alpha=0,05, \mathrm{df}=38$ ).

\section{Conclusions}

Based on the research result, it concluded that Communication Approach Assisted Audio Visual Media in teaching listening achievement could increase the students' 
Proceedings of the $1^{\text {st }}$ Annual International Conference on Language and Literature (AICLL), 18-19 April 2018, Fakultas Sastra, UISU, Medan, Indonesia.

achievement. It means that the experimental group was higher than the mean of controlling group. Although, they were given the same material and test.

Thereby, it could be concluded that giving the different treatment to both of samples caused a significant difference on the students' achievement in listening achievement. The higher score of experiment class was caused by the treatment that applied in this class that was using Communication Approach Assisted Audio Visual Media. Using Communication Approach Assisted Audio Visual Media influenced the students to be more active in the learning process. When the controlling class was taught by using the discussion method that did not give the students time for participating.

It was suggested that English teachers should teach listening more intensively. Because the skill should be understood by the students. Teachers were facilicator in communication in the classroom. The major responsibility was established the situation like to promote communication.

\section{Referencess}

Akram, M., \& Mehmood, A. (2011). The need of communicative approach (in ELT) in teacher training program in Pakistan. Language in India, 11(5), 172-178.

Alan, Mortiboys. (2005). Teaching with Emotional Intellegence. London: Rouledge Arikunto, Suharsimi. (2013). Evaluasi Program Pendidikan. Jakarta: PT Bumi Aksara

Brown, H. D. (1978). Breaking the language barrier: Creating your own pathway to success. Yarmouth: International Press, Inc

Buck. (2001). The Effect of Metacognitive Strategy Training on The Listening Performance of Beginner Students. New York: Mav.Hill

Halliday, M.A.K. (1994). An Introduction to Functional Grammar Second Edition. London: Edward Arnold.

Harmer, Jeremy. (2003). The Practice of English Language Teaching Third Edition Completely Revised and Updated. Harlow: Pearson Education Limited

Mamun, Abdullah. (2014). Effectiveness of Audio-visual Aids in Language Teaching in Tertiary Level. Dhaka: BRAC University

Mittal, Reena. (2000). Communication Approach in Teaching English as a Foreign Language: In reference to Uttar Pradesh. Moradabad: DAK Degree College Moradabad

Nunan, David. (2002). Practical English Language Teaching. New York: Mcgrew Hill Companies

Richard, J. (2006). Communicative Language Teaching. Cambridge: Cambridge University Press

Richards, J \& Rodgers, T. (2001). Approaches and Methods in Language Teaching. Cambridge: Cambridge University Press.

Rusman. (2010). Model-Model Pembelajaran. Jakarta: Rajawali Pers.

Sudijono, Anas. (2011). Pengantar Statistik Pendidikan, Jakarta, PT. Raja grafindo

Syahrum and Salim. (2007). Metodologi Penelitian Kuantitatif. Bandung: Cita Pustaka 